\title{
PENGARUH PEMBERIAN EKSTRAK UMBI BAWANG MERAH (Allium cepa L) TERHADAP KADAR GULA DARAH TIKUS WISTAR (Rattus norvegicus) YANG DIINDUKSI DENGAN ALOKSAN
}

\author{
${ }^{1}$ Bryan Y. Kairupan \\ ${ }^{2}$ Mona P. Wowor \\ ${ }^{2}$ Christi Mambo

\begin{abstract}
${ }^{1}$ Kandidat Skripsi Fakultas Kedokteran Universitas Sam Ratulangi Manado
${ }^{2}$ Bagian Farmakologi dan Terapi Fakultas Kedokteran Universitas Sam Ratulangi

Email: briankairupan@yahoo.co.id
\end{abstract}

\begin{abstract}
People sure that onion bulbs ( Allium cepa L ) has a lot of advantage for health one of which is to lower blood sugar levels. The objective of this research were study the effectiveness of administration of onion bulbs extract on blood glucose levels of Wistar rats (Rattus norvegicus) induced by alloxan. The subject of research using laboratory animals such as male Wistar rats that were 18 samples were divided into 6 groups, the negative control group, and 5 groups of Wistar rats with alloxan-induced hyperglycemic dose of $130 \mathrm{mg} / \mathrm{kg}$ body weight of rats. In the group with hyperglycemic rats given onion bulbs extract at a dose of $9 \mathrm{mg}, 18 \mathrm{mg}$, and $36 \mathrm{mg} / 200 \mathrm{~g}$ body weight of rats, the positive control group was given novomix flexpen, and 1 group were only given alloxan. Data obtained from the results of blood sugar tests in all groups Wistar rats on the first day, second day, third in minutes 0,6 , 12, 18, and 24 hours. The results showed extract of onion bulbs (Allium cepa L) had an effect on blood glucose levels drop Wistar rats that had induced alloxan.
\end{abstract}

Keywords: Allium cepa L, onion bulbs, blood sugar levels, alloxan

\begin{abstract}
Abstrak: Umbi bawang merah (Allium cepa L) diyakini masyarakat memiliki banyak manfaat bagi kesehatan salah satunya yaitu menurunkan kadar gula darah. Penelitian ini bertujuan untuk menguji pengaruh pemberian ekstrak umbi bawang merah terhadap kadar gula darah tikus wistar (Rattus norvegicus) yang diinduksi aloksan. Subjek penelitian menggunakan hewan uji berupa tikus wistar jantan yang berjumlah 18 ekor yang dibagi dalam 6 kelompok, kelompok kontrol negatif, dan 5 kelompok tikus wistar hiperglikemik yang diinduksi aloksan dengan dosis $130 \mathrm{mg} / \mathrm{kg}$ berat badan tikus. Kelompok tikus hiperglikemik diberi ekstrak umbi bawang merah dengan dosis 9 mg, 18 mg, dan 36 mg/ 200 g BB tikus, kelompok kontrol positif diberikan novomix flexpen, dan 1 kelompok yang hanya diberikan aloksan. Data diperoleh dari hasil pemeriksaan gula darah pada semua kelompok tikus wistar pada hari pertama, hari kedua, ketiga pada menit ke- 0 , jam ke- 6, 12, 18, dan 24. Hasil penelitian menunjukkan pemberian ekstrak umbi bawang merah (Allium cepa L) mempunyai efek terhadap penurunan kadar gula darah tikus Wistar yang telah diinduksi aloksan.

Kata kunci: Allium cepa L, Umbi Bawang Merah, Kadar Gula Darah, Aloksan
\end{abstract}

Diabetes melitus (DM) adalah penyakit metabolik dengan karakteristik hiperglikemia kronis serta kelainan metabolisme karbohidrat, protein, dan lemak yang diakibatkan oleh ketidakmampuan sekresi insulin, kerja insulin atau kedua-duanya. Di kalangan masyarakat luas penyakit ini dikenal sebagai penyakit gula atau kencing manis. ${ }^{1-}$ 3 DM dapat diklasifikasikan menurut 
penyebabnya menjadi 4 tipe. Tipe 1 (ketiadaan absolut insulin), tipe 2 (insensitivitas insulin dan defisiensi sekresi insulin), tipe 3 (penyebab spesifik lain), dan tipe 4 (diabetes gestasional). ${ }^{1,4}$

Berdasarkan data International Diabetes Federation (IDF) 2013, Indonesia merupakan negara ke-7 dari 10 negara sedunia dengan jumlah penderita diabetes sebanyak 8,5 juta orang dengan peringkat pertama yang di tempati oleh China dengan prevalensi sebanyak 98,4 juta. ${ }^{5}$ Menurut Riset Kesehatan Dasar (Riskesdas) tahun 2013 prevalensi diabetes yang terdiagnosis dokter, tertinggi terdapat di Sulawesi Tengah (3,7\%), Sulawesi Utara (3,6\%), Sulawesi Selatan (3,4\%) dan Nusa Tenggara Timur (3,3\%). ${ }^{6}$

Salah satu tujuan utama terapi bagi penderita hiperglikemik meliputi pengontrolan kadar gula darah dengan pemberian obat hipoglikemik oral dan insulin. ${ }^{7}$ Namun, seringkali pentalaksanaan tersebut memiliki kemampuan yang terbatas dan mempunyai efek samping yang tidak diingikan. Alasan inilah yang menyebabkan meningkatnya ketertarikan pada penggunaan sumber alami yang berasal dari tumbuhan sebagai salah satu manajemen alternatif dalam menangani pasien diabetes mellitus. ${ }^{3,8}$

Salah satu tanaman berkhasiat obat yang dipercaya masyarakat mampu mengobati demam, antihipertensi, sakit tenggorokan, penyakit kulit, keropos tulang, diabetes, kolesterol tinggi adalah bawang merah (Allium cepa L). ${ }^{9,10} \mathrm{Di}$ Eropa, Asia, dan Timur Tengah, bawang merah sudah lama dijadikan makanan pilihan favorit untuk menurunkan kadar gula darah. Di Puerto Rico, Kuba, dan Santo Domingo telah digunakan secara luas sebagai obat tradisional untuk diabetes. ${ }^{11}$

\section{METODE PENELITIAN}

Penelitian ini dilakukan pada bulan September 2014 - Januari 2015. Penelitian ini dilaksanakan di Laboratorium Farmakologi dan Terapi Fakultas
Kedokteran Universitas Sam Ratulangi Manado. Penelitian ini bersifat eksperimental dan subjek penelitian terdiri dari tikus Wistar (Rattus norvegicus) berjumlah 18 ekor.

\section{ALAT DAN BAHAN PENELITIAN}

Alat yang digunakan dalam penelitian ini terdiri dari wadah plastik, kawat kasa, botol minuman yang disambung pipet, wadah tempat makanan, blender, oven, saringan kasar, corong pemisah, kertas penyaring (kertas Whartman no. 42), cawan petri, labu Erlenmeyer, timbangan analitik, batang pengaduk, gelas ukur, evaporator, pipa nasogastrik, semprit $1 \mathrm{ml}$, cawan porselin, alat ukur gula darah (Nesco multicheck), gunting. Bahan yang digunakan dalam penelitian ini terdiri dari umbi bawang merah, aloksan, novomix, aquades, etanol $70 \%$.

\section{HEWAN UJI}

Hewan uji dibagi dalam 6 kelompok. Pada hari pertama (H1) sebelum perlakuan, semua tikus dipuasakan, kemudian diperiksa kadar gula darah puasa, setelah itu diberikan aloksan dengan dosis 130 $\mathrm{mg} / \mathrm{kg}$ BB tikus untuk menginduksi terjadinya diabetes kecuali pada kelompok kontrol negatif. Kadar gula darah semua tikus diperiksa kembali pada hari kedua (H2) setelah 24 jam penyuntikan aloksan. Pada awal hari ketiga (H3) menit ke-0 kadar gula darah tikus diperiksa sebelum diberi perlakuan pada tiap kelompok.

Masing-masing kelompok diberi perlakuan, untuk kelompok kontrol negatif diberi aquades, kelompok kontrol positif diberi novomix dosis $0,7 \mathrm{U} / \mathrm{kg}$ BB tikus, kelompok yang hanya diberi aloksan, dan kelompok yang diberikan ekstrak daun umbi bawang merah dengan dosis masingmasing 9mg,18 mg, dan $36 \mathrm{mg} / 200 \mathrm{~g} \mathrm{BB}$ tikus. Kadar gula darah pada semua kelompok tikus kemudian diperiksa pada menit ke 0, jam 6, 12, 18, dan 24. Semua sampel darah diambil dari pemotongan ujung ekor tikus dan kadar gula darah 
diukur dengan glukometer Nesco multi check.

\section{Pemberian alloxan}

Dosis alloxan yang diberikan yaitu 110 $\mathrm{mg} / \mathrm{kg}$ BB tikus, dihitung berdasarkan berat badan dari masing-masing tikus dan disuntik secara intraperitonial. ${ }^{12}$

\section{Pemberian Novomix}

Dosis yang digunakan untuk manusia dengan berat rata-rata $50 \mathrm{~kg}$ kadar gula darah puasa $>180 \mathrm{mg} / \mathrm{dl}$ adalah $6 \mathrm{U}$ novomix, ${ }^{13}$ maka dosis yang digunakan pada manusia ialah: $6 \mathrm{U} / 50 \mathrm{~kg}=0,12 \mathrm{U} / \mathrm{kg}$ BB. Digunakan rumus Human Equivalent Dose (HED) based on Body Surface Area (BSA) ${ }^{14}$ maka didapatkan hasil: Dosis manusia $\times \mathrm{K}_{\mathrm{m}}$ faktor manusia/ $\mathrm{K}_{\mathrm{m}}$ faktor tikus. $0,12 \times 37 / 6=0,74 \mathrm{U}$ dibulatkan 0 , $7 / \mathrm{kg}$ BB tikus. Novomix diberikan secara subkutan.

\section{Ekstrak Umbi Bawang Merah}

Bawang merah yang sudah dikeringkan di oven dihaluskan dengan menggunakan blender. Sebanyak 331 gram tepung daun sirsak diekstraksi dengan cara maserasi menggunakan $1000 \mathrm{ml}$ etanol $70 \%$. Setelah dimaserasi selama 5 hari (setiap hari dikocok) hasil larutan disaring terlebih dahulu dengan saringan kasar kemudian disaring dengan menggunakan kertas saring Whartman no.42. Hasil filtrat kemudian dievaporasi dalam oven untuk menguapkan alkohol dan air.

Ekstrak umbi bawang merah diberikan secara oral pada tikus Wistar. Ekstrak hanya diberikan sekali yaitu segera setelah pengukuran kadar gula darah pada hari ketiga (H3) menit ke-0. Ekstrak umbi bawang merah ditimbang sebanyak 1 gram dan dilarutkan dalam $10 \mathrm{ml}$ aquades sampai jenuh. Dosis ekstrak yang akan diberi yaitu $9 \mathrm{mg}, 18 \mathrm{mg}$, dan $36 \mathrm{mg} / 200 \mathrm{~g}$ BB tikus. Pada hewan uji ekstrak umbi bawang merah yang diberi sesuai dengan berat badan rata-rata tikus yang ada yaitu 200 mg. Jadi masing-masing dosis diberikan 0,1 $\mathrm{ml}, 0,3 \mathrm{ml}$ dan $0,5 \mathrm{ml}$ dari larutan ekstrak umbi bawang merah.

\section{HASIL PENELITIAN}

Pengukuran kadar gula darah dilakukan sebanyak tujuh kali yaitu hari pertama sebelum pemberian alloxan (H1), hari kedua (H2), hari ketiga (H3) menit ke0 , dan menit 30, 60, 90,dan 120 setelah perlakuan. Hasil pengukuran kelompok 1 sebagai kontrol negatif dapat dilihat pada Tabel 1; kadar gula darah kelompok 2 yaitu kontrol positif dapat dilihat pada Tabel 2; kadar gula darah kelompok 3 yaitu hanya diberikan alloxan dapat dilihat pada Tabel 3; kadar gula darah kelompok 4 dengan pemberian ekstrak umbi bawang merah dosis $9 \mathrm{mg} / 200 \mathrm{~g}$ BB tikus dapat dilihat pada Tabel 4; kadar gula darah kelompok 5 dengan pemberian ekstrak umbi bawang merah dosis $18 \mathrm{mg} / 200 \mathrm{~g}$ BB tikus dapat dilihat pada Tabel 5; dan kadar gula darah kelompok 6 dengan pemberian ekstrak umbi bawang merah dosis $36 \mathrm{mg} / 200 \mathrm{~g}$ BB tikus pada Tabel 6.

Tabel 1. Kadar Gula Darah Kelompok Negatif yang Hanya Diberikan Aquades

\begin{tabular}{c|c|c|c|c|c|c|c}
\hline \multirow{2}{*}{ Kelompok 1 } & \multirow{2}{*}{$\begin{array}{c}\text { Hari 1 } \\
(\mathrm{mg} / \mathrm{dL})\end{array}$} & \multirow{2}{*}{$\begin{array}{c}\text { Hari 2 } \\
(\mathrm{mg} / \mathrm{dL})\end{array}$} & $\begin{array}{c}0 \\
(\mathrm{mg} / \mathrm{dL})\end{array}$ & $\begin{array}{c}6 \\
(\mathrm{mg} / \mathrm{dL})\end{array}$ & $\begin{array}{c}12 \\
(\mathrm{mg} / \mathrm{dL})\end{array}$ & $\begin{array}{c}18 \\
(\mathrm{mg} / \mathrm{dL})\end{array}$ & $\begin{array}{c}24 \\
(\mathrm{mg} / \mathrm{dL})\end{array}$ \\
\hline Tikus KN1 & 119 & 121 & 69 & 59 & 103 & 78 & 86 \\
\hline Tikus KN2 & 102 & 89 & 124 & 106 & 125 & 120 & 90 \\
\hline Tikus KN3 & 80 & 116 & 107 & 67 & 94 & 90 & 90 \\
\hline Rata-rata & 100,3 & 108,7 & 100 & 77,3 & 107,3 & 96 & 88,7 \\
\hline
\end{tabular}


Kairupan, Wowor, Mambo: Pengaruh pemberian ekstrak umbi bawang ...

Tabel 2. Kadar Gula Darah Kelompok Positif yang Diberi Suntikan Alloxan dan Diberi Suntikan Novomix

\begin{tabular}{c|c|c|c|c|c|c|c}
\hline \multirow{2}{*}{ Kelompok 2 } & \multirow{2}{*}{$\begin{array}{c}\text { Hari 1 } \\
(\mathrm{mg} / \mathrm{dL})\end{array}$} & \multirow{2}{*}{$\begin{array}{c}\text { Hari 2 } \\
(\mathrm{mg} / \mathrm{dL})\end{array}$} & $\begin{array}{c}0 \\
(\mathrm{mg} / \mathrm{dL})\end{array}$ & $\begin{array}{c}6 \\
(\mathrm{mg} / \mathrm{dL})\end{array}$ & $\begin{array}{c}12 \\
(\mathrm{mg} / \mathrm{dL})\end{array}$ & $\begin{array}{c}18 \\
(\mathrm{mg} / \mathrm{dL})\end{array}$ & $\begin{array}{c}24 \\
(\mathrm{mg} / \mathrm{dL})\end{array}$ \\
\hline Tikus KP1 & 81 & 190 & 476 & 450 & 371 & 87 & 600 \\
\hline Tikus KP2 & 74 & 186 & 600 & 600 & 361 & 56 & 436 \\
\hline Tikus KP3 & 116 & 146 & 499 & 369 & 212 & 84 & 509 \\
\hline Rata-rata & 90,3 & 174 & 525 & 473 & 314,7 & 75,7 & 448,3 \\
\hline
\end{tabular}

Tabel 3. Kadar Gula Darah Kelompok yang Hanya Diberi Suntikan Alloxan

\begin{tabular}{c|c|c|c|c|c|c|c}
\hline \multirow{2}{*}{ Kelompok 3 } & \multirow{2}{*}{$\begin{array}{c}\text { Hari 1 } \\
(\mathrm{mg} / \mathrm{dL})\end{array}$} & \multirow{2}{*}{$\begin{array}{c}\text { Hari 2 } \\
(\mathrm{mg} / \mathrm{dL})\end{array}$} & $\begin{array}{c}0 \\
(\mathrm{mg} / \mathrm{dL})\end{array}$ & $\begin{array}{c}6 \\
(\mathrm{mg} / \mathrm{dL})\end{array}$ & $\begin{array}{c}12 \\
(\mathrm{mg} / \mathrm{dL})\end{array}$ & $\begin{array}{c}18 \\
(\mathrm{mg} / \mathrm{dL})\end{array}$ & $\begin{array}{c}24 \\
(\mathrm{mg} / \mathrm{dL})\end{array}$ \\
\hline Tikus A1 & 106 & 181 & 230 & 287 & 321 & 600 & 600 \\
\hline Tikus A2 & 75 & 544 & 550 & 554 & 581 & 600 & 600 \\
\hline Tikus A3 & 77 & 167 & 283 & 300 & 428 & 591 & 600 \\
\hline Rata-rata & 86 & 297 & 354 & 380 & 443 & 597 & 600 \\
\hline
\end{tabular}

Tabel 4. Kadar Gula Darah Kelompok yang Diberi Suntikan Alloxan dan Diberikan Ekstrak Umbi Bawang Merah 9 mg/200 g BB tikus

\begin{tabular}{c|c|c|c|c|c|c|c}
\hline \multirow{2}{*}{ Kelompok 4 } & \multirow{2}{*}{$\begin{array}{c}\text { Hari 1 } \\
(\mathrm{mg} / \mathrm{dL})\end{array}$} & \multirow{2}{*}{$\begin{array}{c}\text { Hari 2 } \\
(\mathrm{mg} / \mathrm{dL})\end{array}$} & $\begin{array}{c}0 \\
(\mathrm{mg} / \mathrm{dL})\end{array}$ & $\begin{array}{c}6 \\
(\mathrm{mg} / \mathrm{dL})\end{array}$ & $\begin{array}{c}12 \\
(\mathrm{mg} / \mathrm{dL})\end{array}$ & $\begin{array}{c}18 \\
(\mathrm{mg} / \mathrm{dL})\end{array}$ & $\begin{array}{c}24 \\
(\mathrm{mg} / \mathrm{dL})\end{array}$ \\
\hline Tikus P1 & 96 & 116 & 373 & 600 & 600 & 540 & 499 \\
\hline Tikus P2 & 58 & 351 & 536 & 537 & 540 & 530 & 470 \\
\hline Tikus P3 & 79 & 265 & 270 & 600 & 600 & 366 & 320 \\
\hline Rata-rata & 77 & 244 & 393 & 579 & 580 & 478 & 429 \\
\hline
\end{tabular}

Tabel 5. Kadar Gula Darah Kelompok yang Diberi Suntikan Alloxan dan Diberikan Ekstrak Umbi Bawang Merah 18 mg/200 g BB tikus.

\begin{tabular}{c|c|c|c|c|c|c|c}
\hline \multirow{2}{*}{ Kelompok 5 } & \multirow{2}{*}{$\begin{array}{c}\text { Hari 1 } \\
(\mathrm{mg} / \mathrm{dL})\end{array}$} & \multirow{2}{*}{$\begin{array}{c}\text { Hari 2 } \\
(\mathrm{mg} / \mathrm{dL})\end{array}$} & $\begin{array}{c}0 \\
(\mathrm{mg} / \mathrm{dL})\end{array}$ & $\begin{array}{c}6 \\
(\mathrm{mg} / \mathrm{dL})\end{array}$ & $\begin{array}{c}12 \\
(\mathrm{mg} / \mathrm{dL})\end{array}$ & $\begin{array}{c}18 \\
(\mathrm{mg} / \mathrm{dL})\end{array}$ & $\begin{array}{c}24 \\
(\mathrm{mg} / \mathrm{dL})\end{array}$ \\
\hline Tikus P1 & 64 & 396 & 600 & 600 & 600 & 550 & 500 \\
\hline Tikus P2 & 84 & 377 & 600 & 600 & 600 & 76 & 62 \\
\hline Tikus P3 & 85 & 121 & 144 & 300 & 349 & 340 & 117 \\
\hline Rata-rata & 77 & 298 & 448 & 500 & 516 & 322 & 226 \\
\hline
\end{tabular}

Tabel 6. Kadar Gula Darah Kelompok yang Diberi Suntikan Alloxan dan Diberikan Ekstrak Umbi Bawang Merah 36 mg/200 g BB tikus

\begin{tabular}{c|c|c|c|c|c|c|c}
\hline \multirow{2}{*}{ Kelompok 6 } & \multirow{2}{*}{$\begin{array}{c}\text { Hari 1 } \\
(\mathrm{mg} / \mathrm{dL})\end{array}$} & \multirow{2}{*}{$\begin{array}{c}\text { Hari 2 } \\
(\mathrm{mg} / \mathrm{dL})\end{array}$} & $\begin{array}{c}0 \\
(\mathrm{mg} / \mathrm{dL})\end{array}$ & $\begin{array}{c}6 \\
(\mathrm{mg} / \mathrm{dL})\end{array}$ & $\begin{array}{c}12 \\
(\mathrm{mg} / \mathrm{dL})\end{array}$ & $\begin{array}{c}18 \\
(\mathrm{mg} / \mathrm{dL})\end{array}$ & $\begin{array}{c}24 \\
(\mathrm{mg} / \mathrm{dL})\end{array}$ \\
\hline Tikus P1 & 74 & 600 & 600 & 462 & 448 & 335 & 280 \\
\hline Tikus P2 & 68 & 430 & 435 & 600 & 536 & 530 & 429 \\
\hline Tikus P3 & 88 & 211 & 219 & 595 & 560 & 420 & 356 \\
\hline Rata-rata & 76 & 413 & 418 & 552 & 514 & 428 & 355 \\
\hline
\end{tabular}




\section{BAHASAN}

Penelitian yang dilakukan merupakan penelitian eksperimental dengan menggunakan hewan coba berupa 18 ekor tikus Wistar yang diberi perlakuan yaitu ekstrak umbi bawang merah. Penelitian ini bertujuan untuk menguji pengaruh pemberian ekstrak umbi bawang merah terhadap kadar gula darah tikus Wistar yang diinduksi dengan aloksan.

Kelompok pertama yaitu kelompok negatif pada hari ketiga menit ke - 0 sampai pada jam ke 24 yang hanya diberikan aquades tidak menunjukan kenaikan atau penurunan yang bermakna.

Kelompok kedua yaitu kelompok kontrol positif yang diberikan aloksan, kadar gula darah tikus meningkat sesudah pemberian aloksan, dan setelah pemberian novomix kadar gula darah tikus menurun. Hal ini disebabkan oleh karena novomix adalah analog insulin manusia yang dapat menurunkan kadar gula darah pada hewan uji. Novomix berikatan dengan resptor insulin untuk meningkatkan ambilan glukosa darah dan menghambat produksi glukosa hepar sehingga dapat menurunkan kadar gula darah. ${ }^{15}$

Kelompok ketiga merupakan kelompok perlakuan yang hanya diberikan suntikan aloksan pada hari pertama, ketiga tikus menunjukkan kenaikan kadar gula darah secara signifikan. Kenaikan kadar gula darah ini dipengaruhi oleh pemberian aloksan sebagai agen diabetogenik yang merusak sel - sel beta pankreas melalui pembentukkan oksigen reaktif dan melewati beberapa proses yang akhirnya merusak DNA pulau Langerhans, selain itu aloksan menghambat reseptor glukosa pada sel beta pankreas. Hal ini yang mengakibatkan kadar gula darah hewan uji meningkat. ${ }^{16,17}$

Pada kelompok perlakuan yang diberikan ekstrak umbi bawang merah dengan dosis terendah $9 \mathrm{mg} / 200 \mathrm{gr}$ BB tikus didapatkan efek hasil penurunan kadar gula darah lebih sedikit dibandingkan dengan dosis $18 \mathrm{mg} / 200 \mathrm{gr}$ BB tikus yang mengalami penurunan pada jam ke 18 sampai dengan 24, sedangkan pada dosis $36 \mathrm{mg} / 200$ gr BB tikus mengalami efek penurunan secara signifikan dimulai pada waktu ke 12, 18 dan 24 jam. Efek penurunan kadar gula darah yang berbeda pada tiap dosis kemungkinan dipengaruhi oleh jumlah konsentrasi ekstrak umbi bawang merah yang berbeda pada tiap dosis pemberian. Kandungan kimia yang terdapat dalam ekstrak umbi bawang merah yaitu kuersetin yang merupakan senyawa sejenis flavonoid yang berfungsi sebagai anti oksidan merevitalisasi sel - sel beta pankreas yang rusak sehingga dapat menghasilkan insulin atau bisa juga berfungsi dalam mekanisme tertentu dalam mempercepat ambilan glukosa darah. ${ }^{18,19}$

\section{SIMPULAN DAN SARAN}

Berdasarkan hasil penelitian maka dapat disimpulkan bahwa ekstrak umbi bawang merah mempunyai efek menurunkan kadar gula darah tikus wistar pada dosis 9 mg/ 200 g BB , 18 mg/200 g BB, dan 36 mg / 200 g BB tikus. Penelitian lanjutan dengan dosis lebih tinggi dan penentuan bahan aktif yang terkandung dalam umbi bawang merah perlu dilakukan.

\section{UCAPAN TERIMA KASIH}

Ucapan terima kasih disampaikan kepada semua pihak yang baik secara langsung maupun tidak langsung telah menumbuhkan idea tau gagasan dalam pemikiran penulis sehingga dapat menyelesaikan penelitian ini.

\section{DAFTAR PUSTAKA}

1. Kumar V, Cotran RS, Robbins SL. Buku Ajar Patologi Robbins, Ed.7, Vol.2. Jakarta: Buku Kedokteran EGC, 2007; hal 718-732

2. Sari DP. Diagnosis dan Klasifikasi Diabetes Melitus. In: Sudoyo AW, Setiyohadi B, Alwi I, Simadibrata M, Setiati S, Editor. Buku ajar Ilmu Penyakit dalam. Edisi V. Jilid III. Jakarta: Pusat Penerbitan Dapertemen Ilmu Penyakit 
Dalam FKUI, 2009; hal 1880-1883

3. Pentalaksanaan Diabetes Melitus Terpadu. Panduan Penatalaksanaan Diabetes Melitus bagi dokter dan educator. Edisi II.

4. Corwin Elizabeth. J. Handbook Of Pathophysiology. $3^{\text {rd }}$ Ed. In: Subekti Nike Budhi, Yudha. K. Egi, Wahyuningshi E, Yulianti D, Karyuni E Pamilih. Jakarta: Buku Kedokteran EGC, 2009; hal 618-622.

5. International Diabetes Federation. Panduan Untuk Manajemen Glukosa PascaMakan [hompage in the Internet]. C2014. [cited 2014 Oct 20]. Available from:

http://www.idf.org/sites/default/files/E N_6E_Atlas_Full_0.pdf.

6. Laporan Riset Kesehatan Dasar 2013. Available from: www.litbang.depkes.go.id/sites/.../rkd2 013/Laporan_Riskesdas2013.PDF.

7. Terapi Untuk Diabetes Melitus [homepaged in the internet]. c2005 [cited2014Oct16]. Availablefrom: http://medicastore.com/diabetes/terapi_ diabetes_mellitus.php.

8. Goodman \& Gilman. Dasar Farmakologi Terapi, Ed. 10, Vol.2. Jakarta : Penerbit Buku Kedokteran EGC; 2008. Hal 1648 - 1678.

9. A'la R, Tim Alfin and Friends, Tim Seloliman PPH, Flo. Perangi Diabetes Melitus dengan Menu Sehat Setiap Hari. Edisi ke-1. Grid Books; 2014.

10. Khasiat Bawang Merah [homepaged in the internet].c2014 [cited 2014 Oct 16]. Available from: http://nyata.co.id/tips/sehat/khasiatbawang-merah-dan-bawang-putih/.

11. Bawang Merah dan Makanan Sarat Serat Untuk Turunkan Kadar Gula Darah [homepaged in the internet]. c2014 [cited 2014 Oct 16]. Available from : http://cuek.wordpress.com/2007/10/09/ bawang-merah-dan-makanan-saratserat-untuk-turunkan-kadar-gula-darah/.
12. Optimasi Dosis Aloksan untuk Induksi Diabetes Menggunakan Hewan Model Tikus Putih Betina[homepaged on the internet].c2014.[cited 2014Oct26]. Availablefrom:

http://ejournal.unesa.ac.id/index.php/jur nal_mipa/article/view/5524

13. Anonim. Novomix 30 Dosing Guidelines. Available from: http://www.novordisk.com/images/diab etes/pdf/novomix_dosing_guidelines_v 18.pdf. Di unduh 26 oktober 2014.

14. Shannon RS, Minakshi N, Nihal A. Dose Translation from Animal to Human Studies Revisited. FASEB Journal Lofe Science Forum:2007;22:659-61.

15. Product Information Insulin Aspartat. [homepaged on the internet]c2012.[cited2015Jan8].Availab lefrom:www.novonordisk.com.au/.../No voRapid_NovoMix_PI3a....

16. Deskripsi Aloksan Monohidrat. [homepaged on the internet]. c2013. [cited2015Jan8]. Availablefrom: http://www.sawitchem.com/post/1/deks kirpsi-alloxan-monohidrat.html

17. Siguard Lenzen. Alloxan and Streptozotocin Diabetes. [cited 2015 Jan 8]. Availablefrom: www.sawleipzig.de/de/projekte/zeitstru kturen.../endo_07-lenzen.pdf

18. Ozougwu, Jevas C. Anti-Diabetic Effects of Allium cepa (Onions) Aqueous Extracts On Alloxan-Induced Diabetic Rattus Norvegicus. Journal of Medicinal Plants Research 2011; Vol 5(7), pp 1134-1139. [SerialOnline]. Available from:

http://www.academicjournals.org/JMP $\mathrm{R}$.

19. Jalal R, Bagheri S, Moghimi A, Rasuli M. Hypoglycemic Effect of Aqueous Shallot and Garlic Extracts in Rats with Fructose-Induced Insulin Resistance. J Clin Biochem Nutr [serial online]. 2007. [cited 2009 Nov 21];41:218-223. Available from: PubMed Central. 